\title{
POSTPONED REPRODUCTIVE MATURATION IN UPLAND REFUGES MAIN- TAINS LIFE-CYCLE CONTINUITY DURING THE HOT, DRY SEASON IN ALGERIAN DRAGONFLIES (ANISOPTERA)
}

\author{
B. Samraoui, S. Bouzid, R. Boulahbal and Philip S. Corbet ${ }^{1}$ \\ University of Annaba, 4 rue Hassi-Beïda, Annaba, Algeria and 'I.C.A.P.B., University of \\ Edinburgh, Scotland, U.K. (Present address: Crean Mill, Crean, St Buryan, Cornwall, \\ U.K.)
}

Received 28 March 1998; revised 21 August 1998; accepted 24 August 1998

Key words: Odonata, seasonal displacement, postponed maturation, aestivation, geographical variation, life cycle, Algeria.

\begin{abstract}
Anisoptera were monitored or sampled regularly at lowland and nearby upland sites in northeastern Algeria during 1992 and 1993. After emerging in lowlands at about sea level in May and June, adults disappeared from lowlands and were then soon encountered in nearby hills at $c a 500-1000 \mathrm{~m}$ a.s.l. where they aestivated in woodland for about three and a half months (Sympetrum meridionale) or more than four months (Aeshna mixta, Sympetrum striolatum). During aestivation adults foraged, gradually changed colour and achieved reproductive maturity. Aestivation ended with the onset of heavy rain in late September or early October when mature adults reappeared at lowland sites where they promptly exhibited reproductive behaviour. Although no adults marked in lowlands were recaptured in uplands, the inference that individual adults made two-way flights between lowlands and uplands is compelling. Postponed reproductive maturation in upland refuges maintains continuity of the life cycle in habitats inimical to survival of the aquatic stages during the protracted hot, dry season. This type of life cycle can be expected to occur in populations of European Odonata near the southern limit of their geographic distribution where they encounter a Mediterranean climate. The implications of such a life cycle for habitat conservation are discussed.
\end{abstract}

\section{Introduction}

Many species of insect exhibit quiescence, diapause or migration as a regular feature of the life cycle that enables them to maintain continuity during seasons inimical to uninterrupted development, or that enables the life cycle to maintain a pattern of voltinism appropriate to the local climate (see Tauber \& Tauber, 1976; Danks, 1987). The adaptive significance of summer diapause (aestivation) in the seasonal regulation of insects has been clearly demonstrated (Masaki, 1961, 1980). Among Odonata, a well documented example is that of Lestes sponsa (Hansemann), a palaearctic zygopteran: its life cycle shows a regression on latitude (or more correctly on mean annual temperature) within its extensive geographical range: north of $40^{\circ} \mathrm{N}$ the adult maturation period lasts about 
20 days, whereas south of $40^{\circ} \mathrm{N}$ it becomes progressively longer until, at the southern most limit of the species' range, it lasts more than 100 days (Uéda, 1978). Several other species of Lestes likewise exhibit aestivation in the immature adult (Bick \& Bick, 1970; Uéda \& Iwasaki, 1982; Utzeri et al., 1988; Agüero-Pelegrin \& Ferreras-Romero, 1992; Jödicke, 1997; Samraoui \& Corbet, in preparation). Some insects combine aestivation with spatial displacement to high (cool) altitudes, returning to lowland reproductive sites in autumn (Masaki, 1980). Such two-way displacement was reported for the aquatic hemipteran Notonecta lactitans Kirk. in South Africa (Hutchinson, 1933) and has recently been detected in N.glauca L. and N.obliqua Gallen in northeastern Algeria (Samraoui in preparation). This syndrome is also a typical feature of many southern populations of the anisopteran libellulid Sympetrum frequens (Sélys) that normally reproduces in lowlands in Japan (Uéda, 1988).

During an ecological survey of Algerian Odonata (Menai, 1993), we were led to hypothesize that three Anisoptera, Aeshna mixta (Latreille), Sympetrum meridionale (Sélys) and S.striolatum (Charpentier), possess a life cycle resembling that of S.frequens (Samraoui et al., 1993). In this paper we present evidence that supports and amplifies this prediction.

\section{Methods}

Study sites

A key feature of the Maghreb (northern Morocco, Algeria and Tunisia) is its geographic isolation due to confinement between the Mediterranean Sea to the north and east and the Atlas Mountains and the Sahara desert to the south. Northeastern Algeria contains three major wetland complexes, forming a crescent around the Edough mountain which ascends to $1008 \mathrm{~m}$. From west to east these complexes comprise: the Guerbes-Senhadja wetlands (Samraoui \& Belair, 1997); Lac Fetzara and surrounding marshes east of Annaba; and the El Kala wetlands (Stevenson et al., 1988). At sea level adult Odonata were monitored at several localities: Lac Tonga $\left(36^{\circ} 51^{\prime} \mathrm{N}, 8^{\circ} 23^{\prime} \mathrm{E}\right)$, a freshwater marsh of 2700 ha; Lac Oubeïra $\left(36^{\circ} 50^{\prime} \mathrm{N}, 8^{\circ} 23^{\prime} \mathrm{E}\right)$, a freshwater lake of 2200 ha; Lac Bleu $\left(36^{\circ} 54^{\prime} \mathrm{N}, 8^{\circ} 20^{\prime} \mathrm{E}\right)$, a freshwater pond of $2 \mathrm{ha}$; and Lac des Oiseaux $\left(36^{\circ} 47^{\prime} \mathrm{N}, 8^{\circ} 7^{\prime} \mathrm{E}\right)$, a freshwater pond of 70 ha. In uplands adults were monitored regularly near Seraïdi on Edough mountain $\left(36^{\circ} 55^{\prime} \mathrm{N}, 7^{\circ} 40^{\prime} \mathrm{E}\right)$ at $c a 450$ and $800 \mathrm{~m}$ a.s.l. in habitats, up to $70 \mathrm{~km}$ from lowland sites, where the main macrovegetative cover was woodland comprising cork oak, Quercus suber L. and dense bushes of Arbuto unedo L., Erica arborea L., Pistacia lentiscus L. and Rubus ulmifolius Schott. In uplands adults were monitored intermittently near Djebel Ghora $\left(36^{\circ} 37^{\prime} \mathrm{N}, 8^{\circ} 26^{\prime} \mathrm{E}\right.$; maximum altitude $\left.1200 \mathrm{~m}\right), 40 \mathrm{~km}$ southeast of El Kala, where one of the few known upland water bodies is located.

Records for screen air temperature and relative humidity and for rainfall were available for lowlands from the Meteorological Station at El Kala, within $10 \mathrm{~km}$ of Lac Oubeïra and Lac Tonga, and for uplands from the Meteorological Station at Seraïdi, within $3 \mathrm{~km}$ of sampling sites on Edough mountain (Table 1). Monthly means for temperature and humidity (all months and May through October only) were compared for the lowland and upland sites applying the One-way ANOVA statistical test. 


\section{Terminology}

By 'exuviae' we mean last-larval-stadium exuviae. 'Adult' means the winged imago, regardless of its postemergence age. Terms describing age-dependent stages of the adult (apart from precise criteria listed in Tables 2-4) are as follows: 'teneral' denotes the condition within about 24 hours after emergence, when the cuticle is almost colourless and still unhardened; 'immature' means post-teneral but not yet mature; and 'mature' means reproductively mature.

Table 1. Climatic variables recorded at El Kala (lowlands) and Seraïdi (uplands) during 1993*.

\begin{tabular}{|c|c|c|c|c|c|c|}
\hline & Tem & ture & Relativ & nidity & Rai & \\
\hline Month & EK & $\mathbf{S}$ & EK & $\mathbf{S}$ & EK & $\mathrm{S}$ \\
\hline January & 11.8 & 7.6 & 74 & 77 & 92.8 & 138.1 \\
\hline February & 11.6 & 5.8 & 74 & 90 & 63.0 & 102.2 \\
\hline March & 12.9 & 8.6 & 74 & 74 & 45.4 & 90.7 \\
\hline April & 15.6 & 11.9 & 73 & 73 & 51.5 & 81.4 \\
\hline May & 18.3 & 16.2 & 76 & 70 & 50.9 & 71.9 \\
\hline June & 21.1 & 19.9 & 70 & 68 & $\operatorname{Tr}$ & 22.0 \\
\hline July & 25.5 & 23.0 & 69 & 60 & 0.0 & $\mathrm{Tr}$ \\
\hline August & 25.8 & 24.5 & 72 & 59 & 0.5 & 2.8 \\
\hline September & 24.2 & 20.8 & 70 & 62 & 26.1 & 52.5 \\
\hline October & 21.4 & 17.3 & 71 & 69 & 83.3 & 80.8 \\
\hline November & 16.1 & 11.3 & 72 & 80 & 48.4 & 70.3 \\
\hline December & 13.1 & 9.0 & 78 & 84 & 125.6 & 210.9 \\
\hline
\end{tabular}

* Temperature (air, in ${ }^{\circ} \mathrm{C}$ ) and relative humidity (as \%), recorded in meteorological screens, and rainfall (as $\mathrm{mm}$ ), all expressed as means for each month.

Abbreviations: EK, El Kala; S, Seraïdi; Tr, unquantifiable trace. 


\section{Sampling}

Emergence of the three species (Aeshna mixta, Sympetrum meridionale and S.striolatum) was monitored quantitatively at three lowland sites during 1992 by making weekly, standardised collections of teneral and recently teneral adults, beginning on 1 May, before emergence began, and ending in the first week of October, long after emergence had ceased. During related projects, not reported here, exuviae were collected systematically from several lowland sites. Abundance of adults of the three species was monitored quantitatively at lowland and upland sites during 1992 and 1993 by making weekly net collections, each lasting $c a 3 \mathrm{~h}$, along transects, each $4 \mathrm{~m}$ wide and $c a 100 \mathrm{~m}$ long. At lowland and upland sites respectively, monitoring or sampling began on 1 May and ended in the first and second week of October. In 1992 more than 2000 adults in lowlands (all teneral) and $c a 1000$ in upland sites (all immature) were marked as individuals, with conspicuous paint spots on the wings, using a code to indicate the place and date of capture, near emergence sites to investigate patterns of possible spatial displacement, including philopatry. Weekly samples of females were dissected to trace ovarian development, and weekly samples of both sexes were used to monitor fresh and dry weight, total lipid, and lipid-free dry weight (LFDW) following the procedure of Uéda (1989). The criterion used to detect maturation of the ovaries was the presence of (any) mature oocytes. This simple binary classification could given the misleading impression that maturation was abrupt even though it may have been gradual. To characterise changes in body colour associated with maturation, arbitrary designations were assigned to successive colour phases (Tables 2-4). For analyses entailing dissection or close inspection, data for Aeshna mixta were less extensive than for the two other species, because adults of A.mixta were consistently much more difficult to capture. Zero entries in Figs. 1-5 between the first and last sampling dates denote that, although sampling was attempted, no specimens were caught. In uplands, qualitative observations (recording presence or absence of adults) were made on certain days when upward movements of dragonflies were suspected.

Unless otherwise qualified, remarks refer to all three species.

\section{Results}

Values in Table 1 correspond closely with those recorded at each site in 1992 except that in 1992 at El Kala average rainfall was very low in September also. Values shown in Table 1 for El Kala resemble average values for temperature, relative humidity and rainfall at that site for 1985-1993. In lowlands during five months (June through October) the mean temperature exceeds $20^{\circ} \mathrm{C}$; and after three exceptionally dry months (June through August) the first heavy rainfall occurs in September or October (Table 1). In the uplands the mean temperature exceeds $20^{\circ} \mathrm{C}$ during three months (July through September) and rainfall is very low in July and August. 
Table 2. Changes during adult maturation of both sexes of Aeshna mixta.

\section{Part of body*}

\begin{tabular}{|c|c|c|c|c|}
\hline Stage & $\mathrm{AB}$ & TH & $\mathrm{CE}$ & CT \\
\hline $\mathrm{T}$ & $\begin{array}{l}\text { Light brown with } \\
\text { creamy grey spots }\end{array}$ & Creamy & Pale grey & $\begin{array}{c}\text { Soft } \\
\text { (teneral) }\end{array}$ \\
\hline M0 & Brownish spots & & Dark grey & Firm \\
\hline M1 & Pale blue spots** & $\begin{array}{l}\text { Light blue, } \\
\text { yellowish tinge }\end{array}$ & Pale blue spots** & \\
\hline M2 & $\begin{array}{l}\text { Brown spots still } \\
\text { darker; segments } \\
\text { 1-3 have yellow } \\
\text { lateral spots }\end{array}$ & Greenish yellow & & \\
\hline M3 & & Yellow** & $\begin{array}{l}\text { Blue; large dorsal } \\
\text { ommatidia deep } \\
\text { blue }^{* *}\end{array}$ & \\
\hline
\end{tabular}

* Abbreviations: AB, abdomen; CE, compound eyes; CT, cuticle; TH, mesepimeron and metepimeron of thorax.

** Colour is paler in female. A female chromatype exists in which yellow replaces blue.

Table 3. Changes during adult maturation of Sympetrum meridionale.

\section{Appearance*}

Stage

Males

$\mathrm{T} \quad$ OC yellow; wings shiny; cuticle soft

M0 Wings no longer shiny; cuticle firm

M1 ST greenish yellow; median dorsal reddish streak on $\mathrm{AB}$ 1-3

M2

M3 HD and AB pale red; ST has reddish tinge

M4 AB tergites entirely red; ST uniform brown; CE reddish brown

\section{Females}

As for males

As for males

OC darker; reddish streak absent on $\mathrm{AB} 1-3$

$\mathrm{AB}$ darker; ST has greenish tinge; DO brown

AB tergites olive-brown; whitish pruinescence on part of ventrum

AB tergites brownish yellow, sometimes reddish; ST dark brown; CE reddish brown; whitish pruinescence covers all sternites

\footnotetext{
* Abbreviations: $\mathrm{AB}$, abdomen; $\mathrm{CE}$, compound eyes; DO, dorsal ommatidia; HD, head; OC, overall colour;
} ST, synthorax. 
Table 4. Changes during adult maturation of Sympetrum striolatum.

\section{Appearance*}

Stage

Males

OC yellow; wings shiny;

flight erratic; cuticle soft

M0 Wings no longer shiny;

flight steady; cuticle firm

M1 OC darker; median dorsal reddish streak on $\mathrm{AB}$; large $\mathrm{DO}$ brown

M2 Reddish streak on $\mathrm{AB}$ wider and on all tergites; TS reddish brown; $\mathrm{AB}$ darker

M3 AB tergites entirely reddish brown; clypeus reddish; large DO reddish brown

M4 AB tergites entirely red; TS red; TH grey
Females

As for males

As for males

OC slightly darker; reddish streak absent on $\mathrm{AB}$

AB olive-brown; ST darker

ST dark; AB swollen; whitish pruinescence on part of ventrum

ST darker; whitish pruinescence covers all sternites

* Abbreviations as in tables 2 and 3 except: TS, mesepisternum and metepisternum.

In all lowland habitats so far monitored, emergence (as revealed by collections of exuviae and, except for Aeshna mixta, teneral adults) closely follows the temporal pattern exhibited by Sympetrum meridionale (Fig. 1).

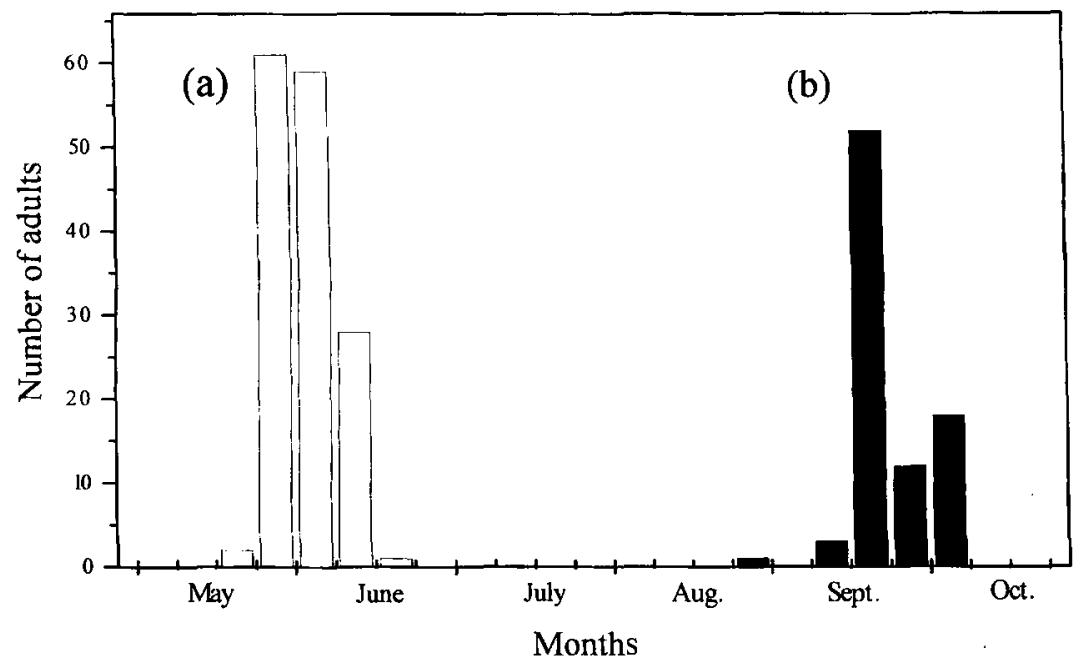

Figure 1. Sympetrum meridionale. Relative abundance of (a) teneral and recently teneral and (b) mature adults at Lac Oubeïra in 1993. 
Collections of exuviae confirmed that all three species emerged each year and that none exhibited a second emergence period. Evidently adults disperse promptly after emergence, because no adult that was not teneral or recently teneral was captured in May and June at Lac Oubeïra or any other lowland site during 1991-1993, and no adult marked at an emergence site was ever recaptured. During 1992 and 1993 an interval of two and three weeks respectively occurred between first recorded emergence (13 and 10 May) in lowland sites and the first sighting in the hills (26 and 30 May). In the hills a separate, slow and local displacement of aestivating dragonflies, as evidenced by resighting of individuals marked in uplands, seemed to correlate with high temperature and low relative humidity, although no consistent directional displacement was detected. Relative humidity in the lowlands dropped abruptly from well over $60 \%$ as soon as the hot, dry (sirocco) wind arrived from the Sahara. At the same time (inferred from three discrete events) a pronounced upward displacement of dragonflies was observed over a distance of several $100 \mathrm{~m}$. During spells of the sirocco, typically lasting 3-5 days, aestivating dragonflies disappeared from the altitudinal range $400-800 \mathrm{~m}$ and could be found only above $c a 1000 \mathrm{~m}$ altitude.
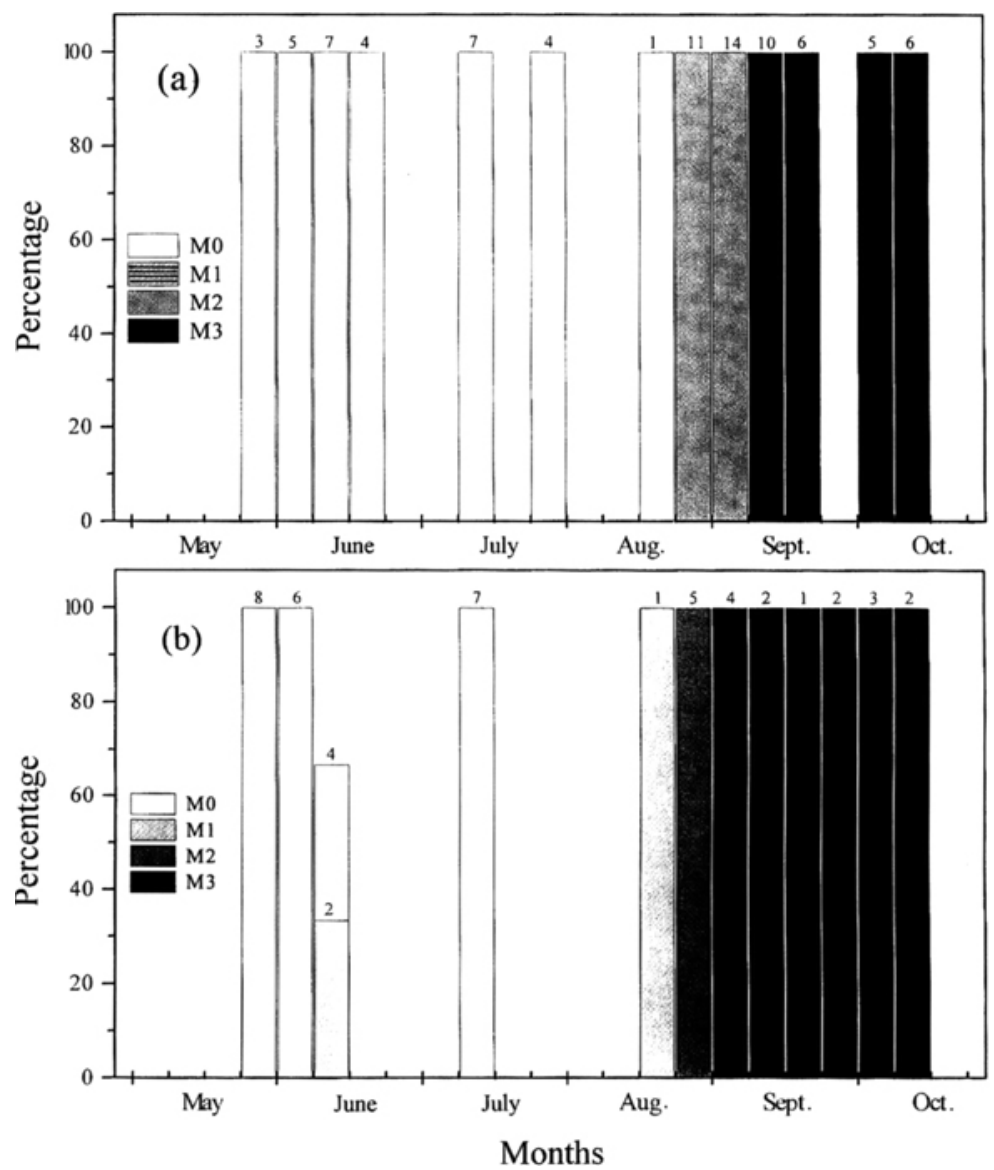

Figure 2. Aeshna mixta. Seasonal distribution of successive maturation stages at upland aestivation sites in 1993: (a) males (stage M1 was not encountered in 1993); and (b) females. Numbers above bars denote sample sizes. 
Although changes of body colour were continuous during aestivation (Tables 2-4; Figs 2-4) and probably reflected biochemical and physiological development, the ovaries appeared to mature abruptly (Fig. 5), perhaps because of the binary criterion we used to detect ovarian maturity. Mature oocytes (i.e. eggs) of Sympetrum meridionale were first observed in ovaries in mid-September (1992) and the last week of August (1993), and those of S.striolatum at the end of September (both years). Records from the small number of Aeshna mixta examined are consistent with the first eggs in ovaries appearing
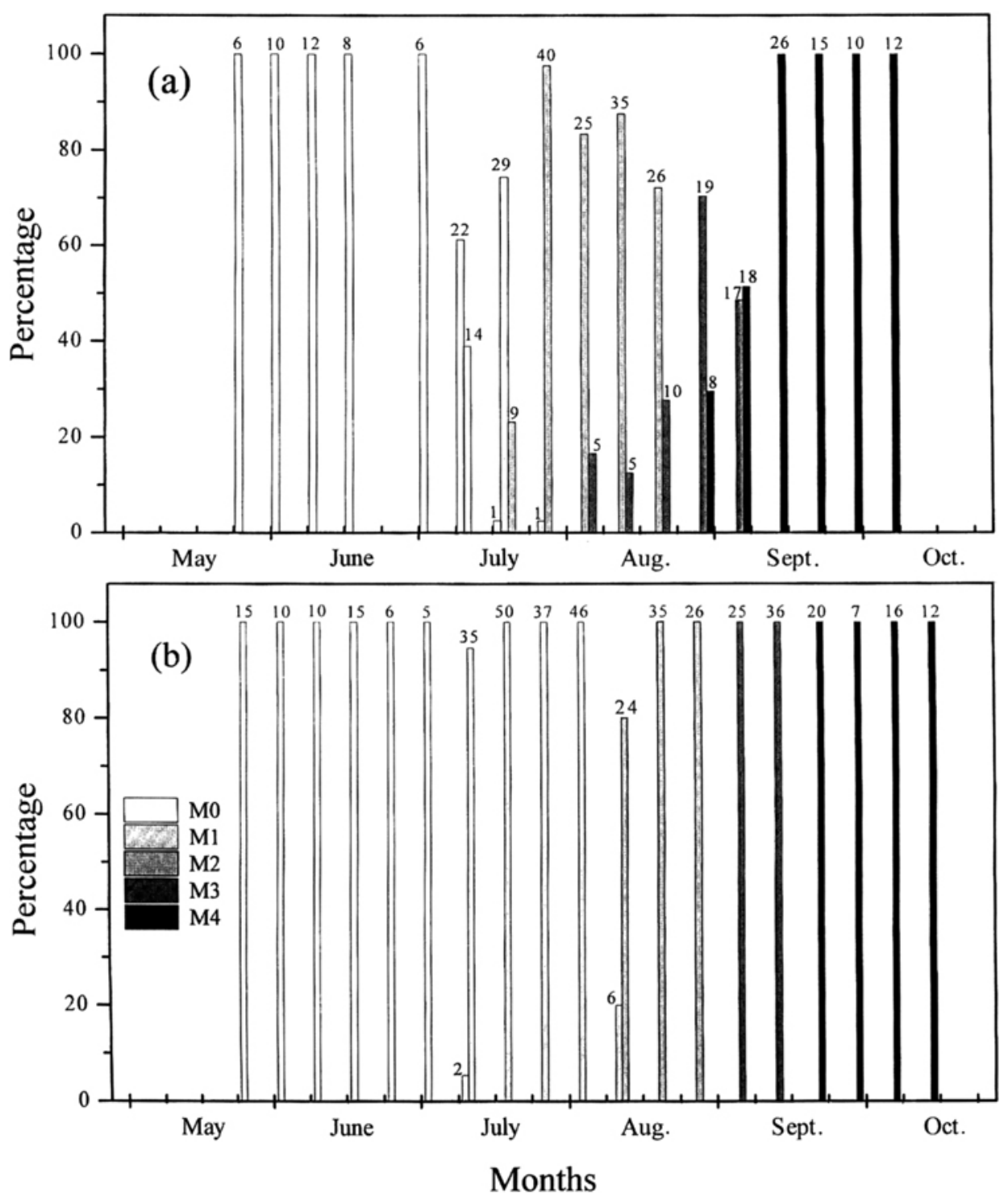

Figure 3. Sympetrum meridionale. Seasonal distribution of successive maturation stages at upland aestivation sites in 1993: (a) males; and (b) females. Numbers above bars denote sample sizes. 
at the end of September or the beginning of October. To judge by changes of body colour, males (of all three species) matured at the same time as females. Throughout aestivation adults showed an increase in dry weight, lipid and LFDW (Figs 6-8). (The data for fresh weight provided no additional information and so are not presented.) Towards the end of maturation, the variables of sex and stage of development are interactive, and transition from M3 to M4 results in a proportionately greater change to the mean mass of females for both species of Sympetrum (Figs 6-8). Table 5 records the computed Two-way ANOVA F
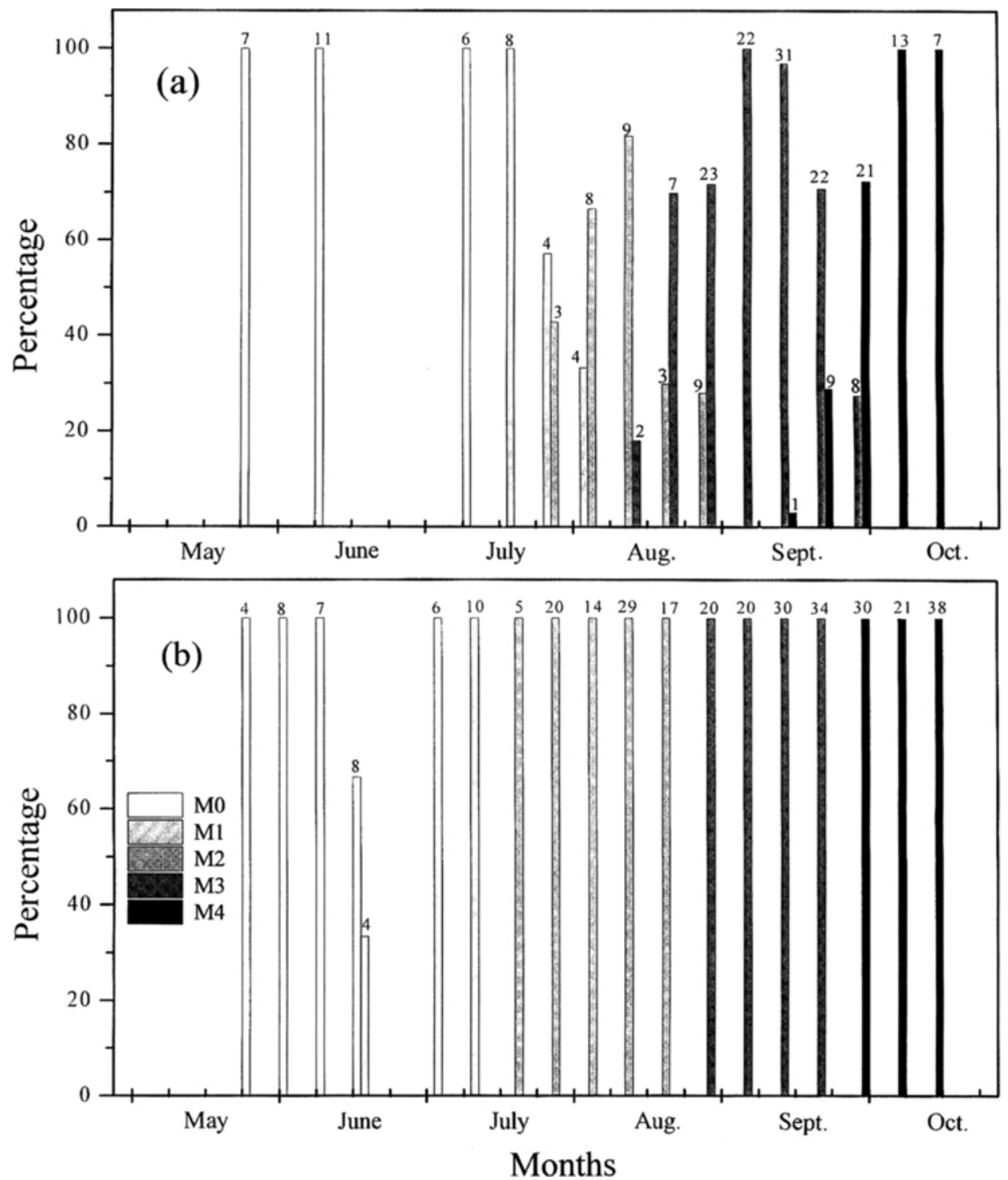

Figure 4. Sympetrum striolatum. Seasonal distribution of successive maturation stages at upland aestivation sites in 1993: (a) males; and (b) females. Numbers above bars denote sample sizes. 
(interaction) between sex and stage. Although no adult marked in lowlands was recaptured, appearance of mature adults in lowland sites allows the inference that aestivation lasts about three and a half months in Sympetrum meridionale and exceeds four months in Aeshna mixta and S.striolatum.
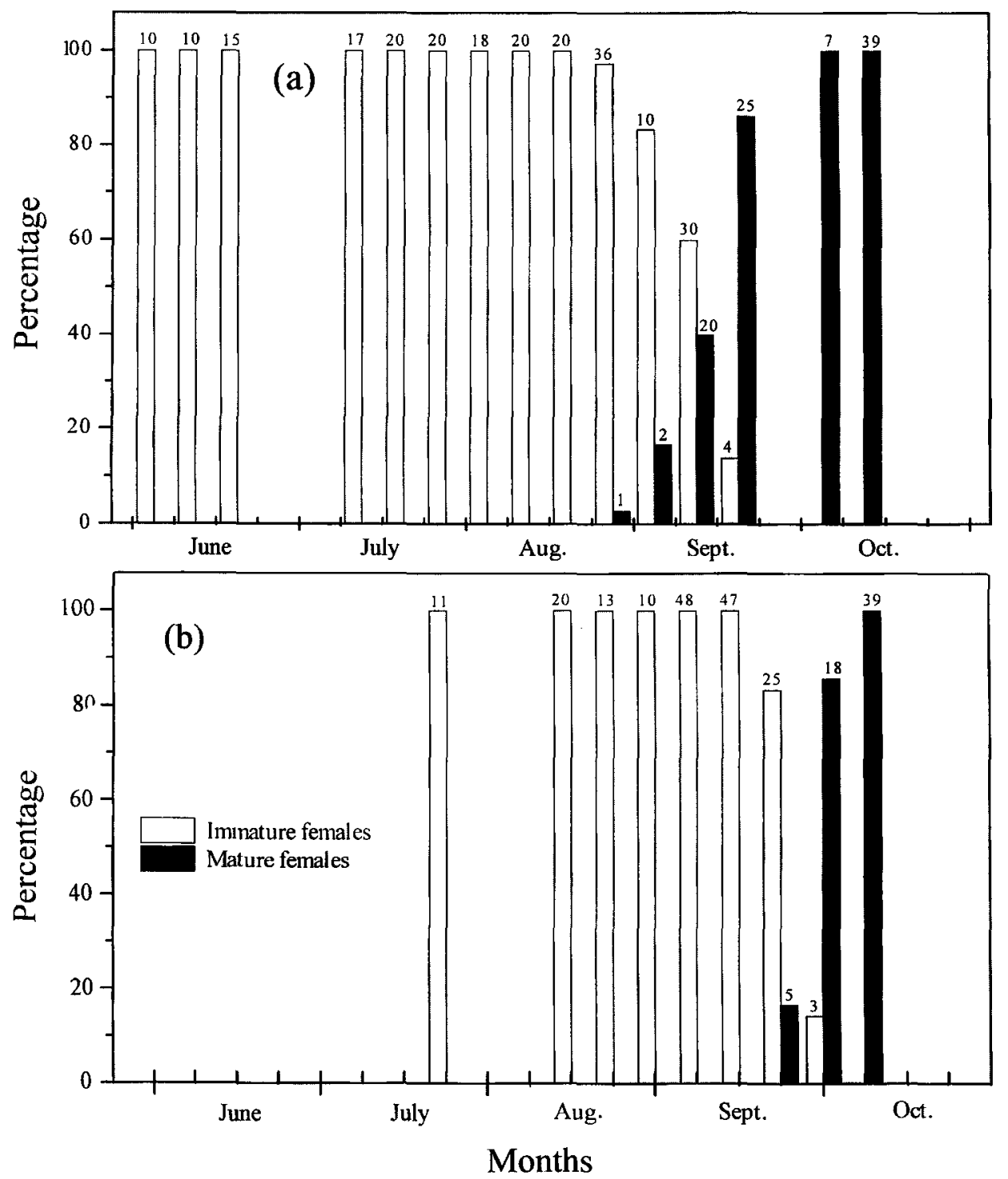

Figure 5. Seasonal maturation of ovaries of (a) Sympetrum meridionale and (b) S.striolatum at upland aestivation sites in 1993. Mature females are those containing mature oocytes. Numbers above bars denote sample sizes. 

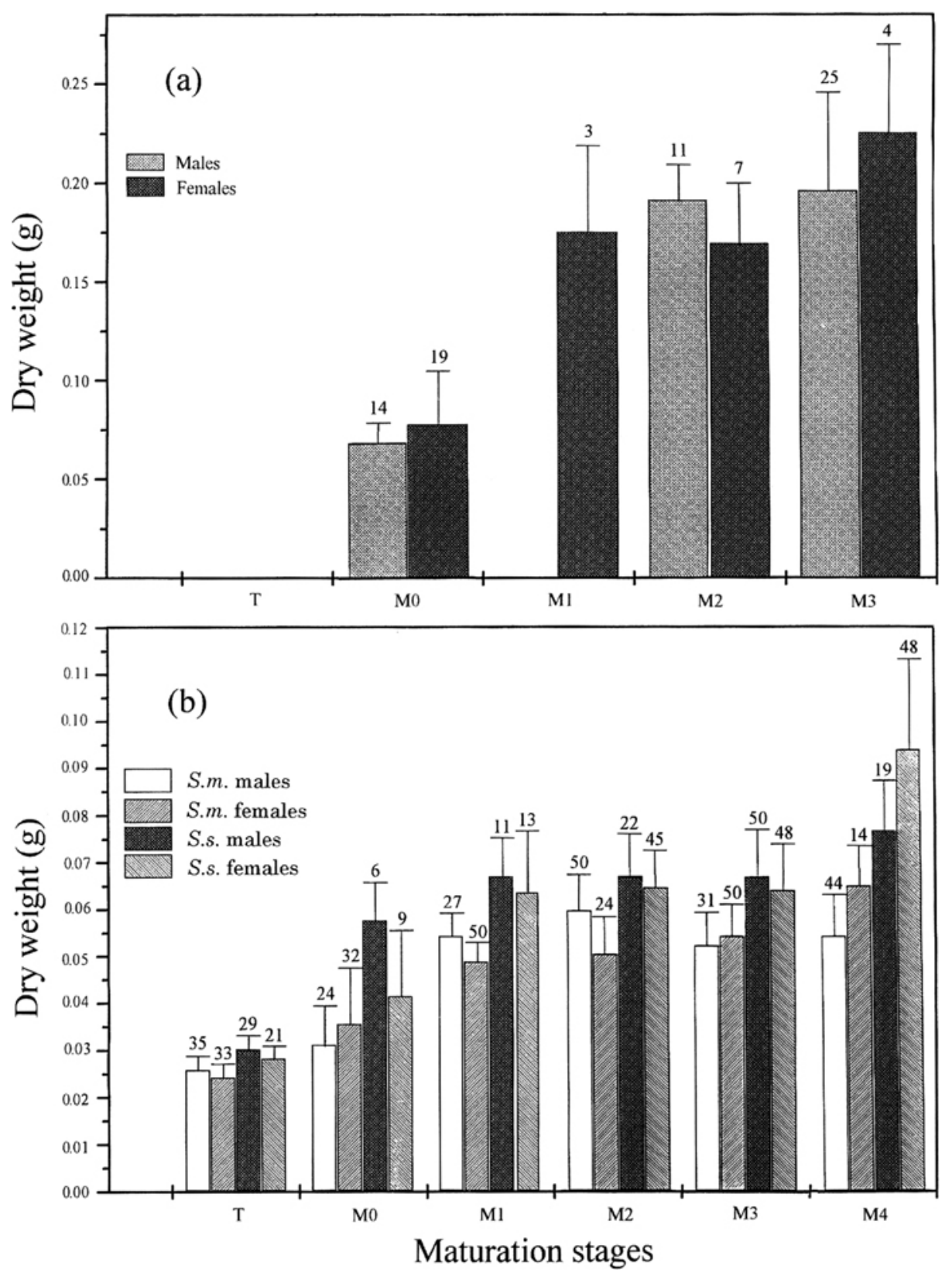

Figure 6. Changes in dry weight of (a) Aeshna mixta and (b) Sympetrum meridionale and S.striolatum at upland aestivation sites in 1993. Vertical bars denote Standard Errors. Numbers above bars denote sample sizes. Differences between males and females in stage M4, revealed by One-way ANOVA tests, are significant in S.meridionale $\left(\mathrm{F}_{1.5 \mathrm{t}}=16.65, P<0.001\right)$ and S. striolatum $\left(\mathrm{F}_{1.66}=15.97, P<0.001\right)$. 
Adults of Aeshna mixta and Sympetrum striolatum, especially the former, exhibited intense intramale interaction at reproductive sites. Female A.mixta usually oviposited 2-3 $\mathrm{m}$ from the water's edge, in stems of Schoenoplectus lacustris (L.) which were covered by water after the first heavy rains in autumn. Both species of Sympetrum oviposited in free water, and also occasionally on a dry surface.

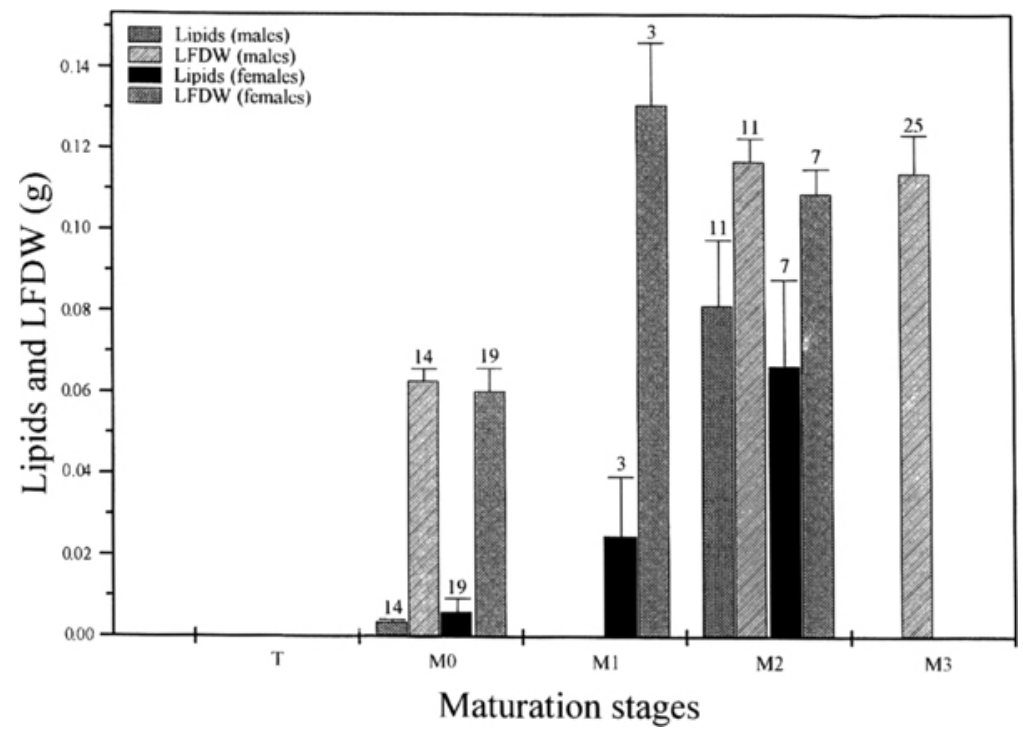

Figure 7. Changes in lipids and LFDW of Aeshna mixta at upland aestivation sites in 1993. Vertical bars denote Standard Errors. Numbers above bars denote sample sizes. Data are unavailable for M3 except for LFDW (males).

Table 5. Results of Two-way ANOVA tests for interaction between sex and maturation in stages M3 and M4 in two species of Sympetrum.

Dependent

$\begin{array}{lllll}\text { Species } & \text { variable } & \mathrm{N}^{*} & \text { Interaction (F) } \quad P\end{array}$

Sympetrum meridionale

$\begin{array}{llll}\text { Dry weight } & 14 & \mathrm{~F}_{1.52}=23.09 & <0.001\end{array}$

LFDW $\quad 5 \quad \mathrm{~F}_{1,16}=25.45 \quad<0.001$

\begin{tabular}{llclr}
\hline S. striolatum & Dry weight & 15 & $F_{1,56}=60.39$ & $<0.001$ \\
& LFDW & 5 & $F_{1.16}=10.14$ & 0.006
\end{tabular}

*The number of specimens of each sex in each of stages M3 and M4; thus, a total of 56 (i.e. 4 X 1) specimens of S.meridionale were analysed for dry weight. 

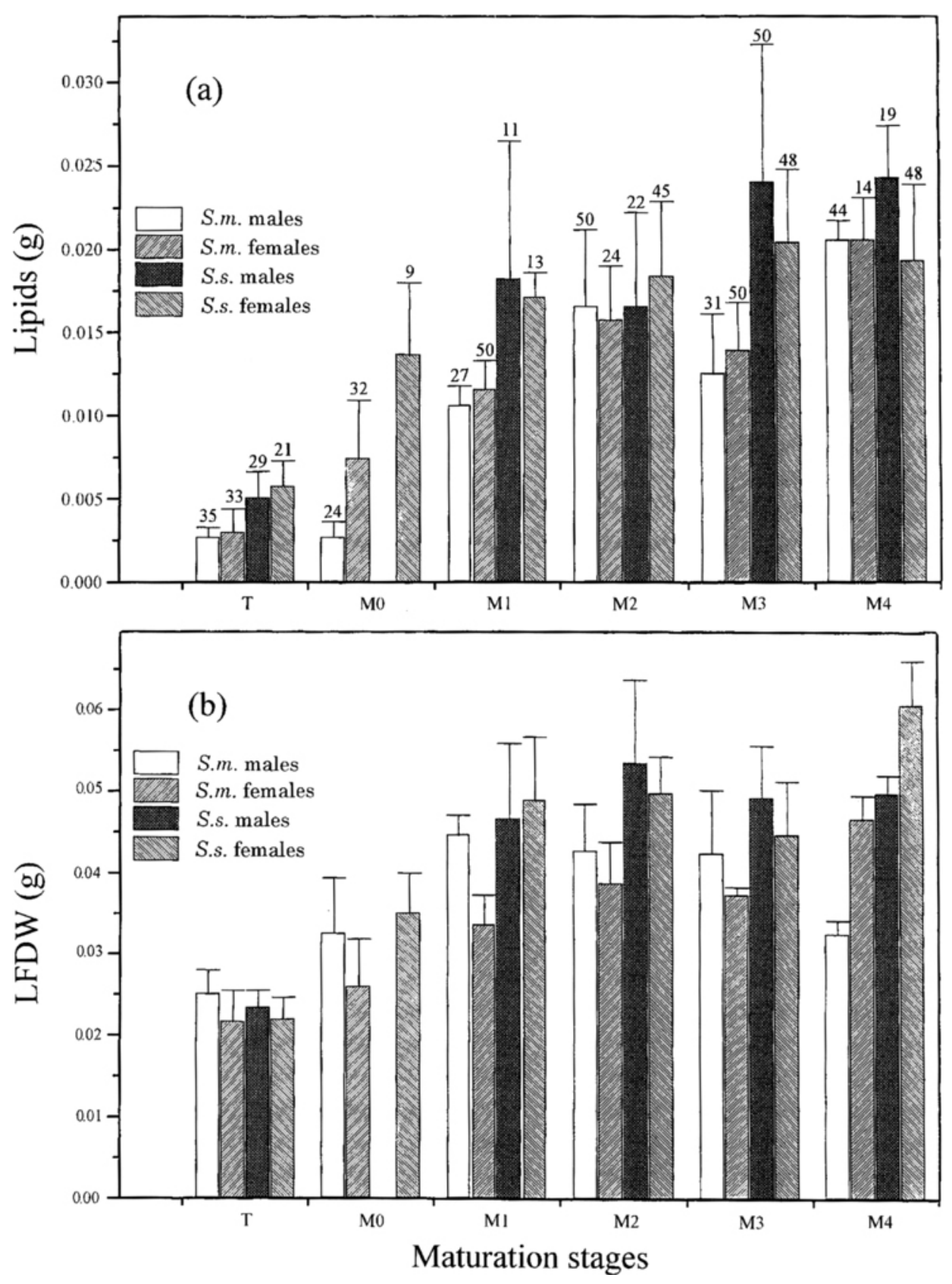

Figure 8. Changes in (a) lipids and (b) LFDW in Sympetrum meridionale and S.striolatum at upland aestivation sites in 1993. Vertical bars denote Standard Errors. Numbers above bars in (a) denote sample sizes in (a) and (b). Differences between males and females in stage M4, revealed by One-way ANOVA tests, are significant in S.meridionale $\left(\mathrm{F}_{1.8}=85.12, P<0.001\right)$ and S.striolatum $\left(\mathrm{F}_{1.8}=16.30, P<0.01\right)$. Data in (a) and (b) are unavailable for M0 for S.striolatum males. 


\section{Discussion}

The typically Mediterranean climate of northeastern Algeria features two distinct seasons: a wet season with highly variable rainfall during October through May; and a hot season with very low rainfall during the summer (June through most of September). Although in northeastern Algeria atmospheric humidity may be high during the summer because of extensive wetlands, the lack of rain and therefore free water in their habitats (rivers, lakes, ponds) presents a major constraint for dragonflies whose larvae and sometimes eggs depend on free water to remain viable.

No adult marked in lowland sites was recaptured in upland sites, a result readily accounted for by mortality, dispersion and massive dilution. Nevertheless, because no adult that was not teneral or obviously recently teneral was found at any lowland site during the summer, and because no reproductive site for any of the three species was discovered in the upland aestivation sites (Djebel Ghora did not harbour breeding populations of any of the three species), one may confidently infer that upland populations derive predominantly from lowland sites. Whereas adults marked in lowlands were never resighted, adults marked (first) in uplands in stages M0 and M1 were sometimes sighted close to the place of marking, on several subsequent days during the week following first capture. The interval between emergence in lowland sites and arrival in the hills is consistent with the intervening distance (up to $35 \mathrm{~km}$ ) being traversed gradually, in stages. If displacement occurs in such a way, it is unlikely that thermals play a part in the translocation. The silhouette of the hills that flank the coastal plains of the El Kala region and Annaba perhaps offers a directional cue to the travelling dragonflies, as happens in the chafer, Melolontha melolontha (L.) (Couturier \& Robert, 1955 in Jander, 1963) but this supposition would be difficult or impossible to test.

Microclimatic conditions offered by the cork oak and zeen oak (Quercus faginea Laml.) woodland in the hills may enhance survival during aestivation by reducing metabolic rate and water loss. Statistical comparison between temperature and humidity in uplands and lowlands respectively (based on values in Table 1and applying the One-way ANOVA test) reveals no significant differences, perhaps because of the short data set and the variation among constituent values. However observations in the field indicate that critical differences may exist for only a few days at a time, while the sirocco wind is blowing from the south. During such episodes, desiccation in lowlands is extreme. In uplands we hypothesize that aestivating dragonflies might obtain relief by moving upwards, perhaps also occupying the northern (lee) side of hills. During the sirocco aestivating dragonflies on Djebel Ghora disappeared from their normal altitude of 400-800 $\mathrm{m}$ and were encountered only above $c a 1000 \mathrm{~m}$.

The lifespan of adults that survive aestivation is among the longest known for Anisoptera in temperate latitudes. Post-teneral development proceeds throughout aestivation but much more slowly than in congeneric non-aestivating species, such as Aeshna affinis Vander Linden and Sympetrum sanguineum (Müller) (Berkous \& Dermouchi, 1993). Further study is needed to determine whether ovarian maturation is abrupt or gradual.

From unpublished work conducted at the University of Annaba, we know that in the study area all three species are univoltine and normally lack embryonic diapause. Our findings contrast with those for European populations of Aeshna mixta in which embryonic 
diapause is apparently typical (Gardner, 1950; Schaller, 1968). Populations of the three species that we studied are close to the southern limit of their geographical distribution (Askew, 1988) and subject to a climate not encountered in the rest of their range, except around parts of the north coast of the Mediterranean Sea. By analogy with the inferred pattern shown by Sympetrum frequens in Japan (Uéda, 1988), we predict that prolonged aestivation is confined to populations that experience a Mediterranean climate. Indeed, this phenomenon has recently been detected in populations of Aeshna mixta in southern Spain (Muñoz-Pozo \& Ferreras-Romero, 1996) and inferred as likely in S.striolatum in southern Spain (Von Hagen, 1996), although neither of these reports contained evidence or supposition that aestivation occurred in uplands. It remains to be discovered whether prereproductive aestivation exists only in populations subject to a Mediterranean climate or whether in some or all more northerly populations there exists the potential for its expression, so that during unusually hot, dry summers it becomes manifest. A separate matter is the extent to which adult aestivation is associated with displacement to an upland refuge. In S.frequens such an association appears to depend, at least partly, on temperature during early summer, but perhaps also on the sufficiently close proximity of suitable hills (Uéda, $1988,1993 \mathrm{a}, \mathrm{b})$. The three species that we report on in this paper are widespread in Europe, and offer rich material for research focused on the incidence of postponed reproductive maturation and associated displacement to upland refuges.

The three species that aestivate in uplands in northeastern Algeria have all been seen elsewhere to undertake mass directional flights, sometimes when immature and sometimes when mature, and sometimes over the sea, far from land (Corbet, 1962). The spatial displacement we have described in this paper falls into the category of a "seasonal refuge flight" and is probably behaviourally and functionally distinct from "migration"; accordingly, when adults of any of the three species are encountered flying en masse over the sea, the possibility should be allowed that this may have resulted from diversion of a flight to or from an aestivation refuge (Corbet, 1999). The arrival of adults in lowlands in late summer, interpreted by us as a return flight, perhaps involves philopatry and spatial orientation based on spatial memory. However we have no evidence of this, and the prevalence and extent of lowland water bodies in early autumn, and the means available to dragonflies to detect them optically (Schwind, 1991; Horváth, 1995), would seem to make it unnecessary to invoke the operation of spatial memory in this instance.

The phenomenon we have documented in northeastern Algeria has an important bearing on strategies for conserving species and therefore their habitats. In the El Kala region the habitat needed by each of the species we report on here comprises not only lowland lacustrine biotopes where reproduction occurs and where eggs and larvae develop, but also upland forested sites that may be many kilometres away. Recently (1993-1995) devastating fires have swept through large forested areas in uplands in the El Kala region, and populations of all three species have declined abruptly.

\section{Acknowledgments}

We thank the late Peter Miller, to whom we respectfully dedicate this paper, for having dissected some immature dragonflies from upland sites; staff of the Meteorological Stations at El Kala and Seraïdi for having made records available to us; and an anonymous reviewer for valued comments on the manuscript.. 


\section{References}

Agüero-Pelegrin, M. \& M. Ferreras-Romero, 1992. Dynamics of a dragonfly community in a man-made lake of the Sierra-Morena, Andalusia, Southern Spain (Odonata). Opuscula Zoologica Fluminensis 83: 1-7.

Askew, R.R., 1988. The Dragonflies of Europe. Harley, Colchester, 291 pp.

Berkous, M. \& A. Dermouchi, 1993. [Contribution to the study of summer diapause in Aeshna and Sympetrum (Odonata) in N.E.Algeria.] Mémoire de D.E.S., University of Annaba. [In Arabic.]

Bick, G.H. \& J.C. Bick, 1970. Oviposition in Archilestes grandis (Rambur) (Odonata: Lestidae). Entomological News 81: 157-163.

Corbet, P.S., 1962. A Biology of Dragonflies. Witherby, London, xvi $+247 \mathrm{pp}$.

Corbet, P.S., 1999. Dragonflies: Behavior and Ecology of Odonata. Cornell University Press, Ithaca, in press.

Danks, H.V., 1987. Insect dormancy: an ecological perspective. Biological Survey of Canada (Terrestrial Arthropods), Ottawa, $x+439$ pp.

Gardner, A.E., 1950. The life-history of Aeshna mixta Latreille (Odonata). Entomologist's Gazette 1: 128-138.

Horváth, G., 1995. Reflection-polarization patterns at flat water surfaces and their relevance for insect polarization vision. Journal of Theoretical Biology 175: 27-37.

Hutchinson, G.E., 1933. The zoogeography of the African aquatic Hemiptera in relation to past climatic change. Internationale Revue der gesamten Hydrobiologie und Hydrographie 28: 436-468.

Jander, R., 1963. Insect orientation. Annual Review of Entomology 8: 95-114.

Jödicke, R., 1997. Die Binsenjungfern und Winterlibellen Europas. Westarp Wissenschaften, Magdeburg. Spektrum Akademischer Verlag, Heidelberg.

Masaki, S., 1961. Geographical variation of diapause in insects. Bulletin of the Faculty of Agriculture, Hirosaki University 7:66-98 .

Masaki, S., 1980. Summer diapause. Annual Review of Entomology 25: 1-25.

Menai, R., 1993. Contribution à la mise à jour de l'odonatofaune algérienne. Thèse de Magister, University of Annaba.

Muñoz-Pozo, B. \& M. Ferreras-Romero, 1996. Fenologia y voltinismo de Aeshna mixta Latreille, 1805 (Odonata, Aeshnidae) en Sierra Morena (Sur de España). Boletin de la Real Sociedad Española de Historia Natural, Sección Biológica 92: 239-244.

Samraoui, B., in preparation. On the ecology of Notonecta (Hemiptera: Notonectidae) in northeastern Algeria.

Samraoui, B. \& G. de Belair, 1997. The Guerbes-Senhadja wetlands (N.E.Algeria): an overview. Ecologie 28: 233-250.

Samraoui, B. \& P.S. Corbet, in preparation. Seasonal regulation in Algerian Lestidae (Odonata: Zygoptera).

Samraoui, B., S. Bouzid, R. Boulahbal \& P.S. Corbet, 1993. Seasonal migration and prereproductive diapause in Aeshna mixta, Sympetrum meridionale and S.striolatum as an adaptation to the Mediterranean climate (N.E.Algeria). Abstracts of the Twelfth International Symposium of Odonatology, Osaka, Japan: 33-34.

Schaller, F., 1968. Action de la température sur la diapause et le développement de l'embryon d'Aeschna mixta (Odonata). Journal of Insect Physiology 14: 1477-1483. 
Schwind, R., 1991. Polarization vision in water insects and insects living on a moist substrate. Journal of Comparative Physiology A 169: 531-540.

Stevenson, A.C., J. Skinner, G.E. Hollis \& M. Smart, 1988. The El Kala National Park and its environs: an ecological evaluation. Environmental Conservation 15: 335-348.

Tauber, M.J. \& C.A. Tauber, 1976. Insect seasonality: diapause maintenance, termination, and post-diapause development. Annual Review of Entomology 21: 81-107.

Uéda, T., 1978. Geographic variation in the life-cycle of Lestes sponsa. Tombo, Tokyo 21: 27-34.

Uéda, T., 1988. Diversity in the life history of Sympetrum frequens (Odonata: Insecta). Bulletin of Ishikawa Agricultural College 18: 98-110.

Uéda, T., 1989. Sexual maturation, body colour changes and increase of body weight in a summer diapause population of the damselfly Lestes sponsa (Hansemann) (Zygoptera: Lestidae). Odonatologica 18: 75-87.

Uéda, T., 1993a. [Questions in the life history of Sympetrum frequens, Part 1.] Insectarium, Tokyo 30: 292-299. [In Japanese.]

Uéda, T., 1993b. [Questions in the life history of Sympetrum frequens, Part 2.] Insectarium, Tokyo 30: 346-355. [In Japanese.]

Uéda, T. \& M. Iwasaki, 1982. Changes in the survivorship, distribution and movement pattern during the adult life of a damselfly, Lestes temporalis (Zygoptera: Odonata). Advances in Odonatology 1: 281-291.

Utzeri, C., G. Carchini \& E. Falchetti, 1988. Aspects of demography in Lestes barbarus (Fabr.) and L.virens vestalis Ramb. (Zygoptera: Lestidae). Odonatologica 17: 107 -114. Von Hagen, H., 1996. Neue Beobachtungen zur Odonatenfauna Mallorcas. Advances in Odonatology, Supplement 1: 29-33. 